\title{
PROFISSIONALIZAÇÃO E EXPANSÃO DA MUSEOLOGIA NO BRASIL
}

Há tempos o museu deixou de ser visto, simplesmente, como um espaço físico que guarda peças antigas, desconectadas do cotidiano da população e da atualidade. Hoje, é um espaço que conserva e preserva coleções de caráter cultural a técnico-científico, dialoga com seu público e difunde conhecimento, e contribui para o desenvolvimento de outros setores, como o turismo e a geração de empregos. Em levantamento feito pelo Cadastro Nacional de Museus, existem no Brasil hoje 3.025 museus, dado publicado em Museus em números, de 2010, do Instituto Brasileiro de Museus (Ibram)/Ministério da Cultura (MinC). "É um campo em expansão, com franco desenvolvimento e singular organização", afirma Maria Cristina Oliveira Bruno, museóloga e coordenadora do programa de pós-graduação Interunidades em Museologia da Universidade de São Paulo (USP).

No plano federal, a última década apresentou mudanças significativas: em 2003 foi instituída a Política Nacional de Museus e, em 2009, foram criados o Estatuto dos Museus e o Ibram. Segundo Valdemar de Assis Lima, museólogo do Ibram, "o Estatuto presta um serviço extremamente profícuo aos museus e seus profissionais, especialmente, por defender a elaboração e aplicação dos Planos Museológicos, ferramenta de gestão fundamental para a proteção das instituiçõos e processos museais, além de contribuir para o seu fortalecimento e o cumprimento de sua função social". Por sua vez, o Ibram, uma autarquia vinculada ao Ministério da Cultura, que coordena a Política Nacional de Museus, corresponde a um antigo anseio da comunidade museológica, afirma Maria Eugênia Saturni, diretora secretária do Conselho Federal de Museologia (Cofem).

A regulamentação da museologia, por meio de leis e instituições próprias, também contribuiu para seu desenvolvimento. "A museologia é, portanto, uma profissão regulamentada e o exercício de algumas atividades museológicas são privativas dos profissionais formados na área e registrados nos Conselhos Regionais de Museologia, que são disciplinados pelo Conselho Federal de Museologia (Cofem) que estabeleceu o Código de Ética Profissional do Museólogo. Os Conselhos Regionais de Museologia são responsáveis pela fiscalização e registro das atividades de regulamentação da profissão em seus referidos territórios", explica Maria Eugênia. A interdisciplinaridade é uma marca desse campo de conhecimento. "Cada vez mais há uma necessidade de diálogo en-

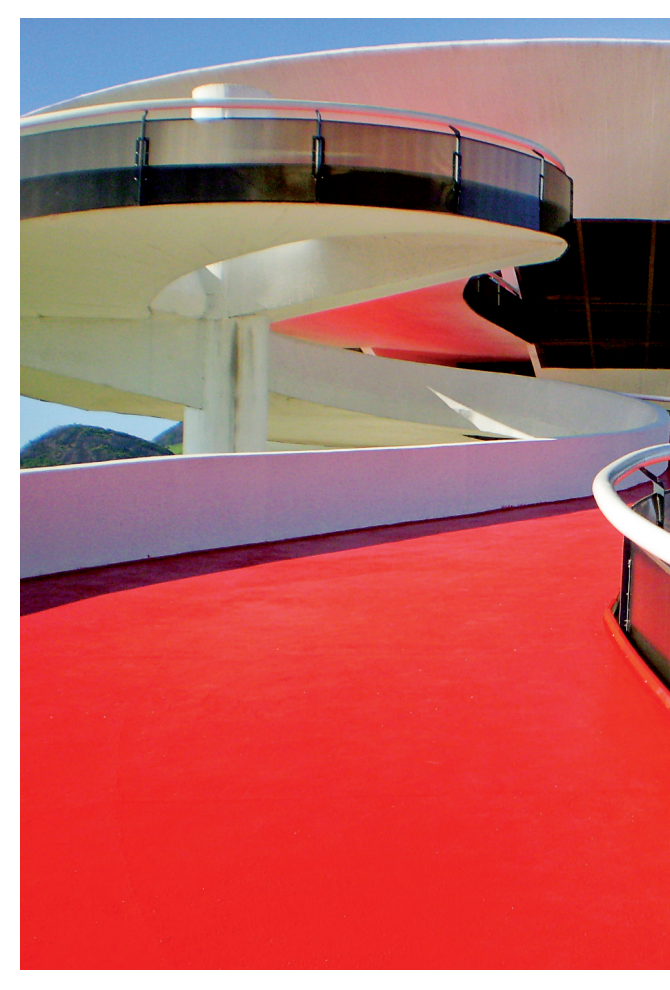

tre as ciências e os saberes populares", complementa Lima.

PROFISSIONALIZAÇÃo O primeiro curso de museologia no Brasil surgiu em 1932 no Museu Histórico Nacional (MHN). "O intuito era promover o aperfeiçoamento da mão de obra dos funcionários do museu. $\mathrm{Na}$ época, quem concluía o curso era chamado de 'conservador de museus', termo traduzido do francês", explica a diretora do MHN, Vera Tostes. Atualmente, entre os profissionais do MHN, estão museólogos, historiadores e profissionais das área de pedagogia, restauração e conservação, biblioteca e arquivo.

O país tem 14 cursos de graduação, um programa de mestrado e doutorado na Universidade Federal do Estado do Rio de Janeiro (Unirio) e 
